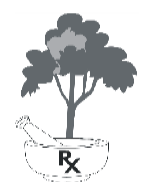

\title{
Stabilization potential of acidified corn starch in vitamin $E$ enriched coconut oil emulsions for extemporaneous topical formulations
}

\author{
Oladapo A. ADETUNJI* and Tobilola O. AKINGBADE \\ Department of Pharmaceutics \& Industrial Pharmacy, Faculty of Pharmacy, University of Ibadan, Nigeria
}

Received $10^{\text {th }}$ June 2020; Accepted 24 ${ }^{\text {th }}$ August 2020

\begin{abstract}
In this study, the stabilizing potential of corn starch acidified with hydrochloric acid (ACS) in comparison with Tween $80^{\circledR}$ was evaluated in vitamin $\mathrm{E}$ enriched coconut emulsions for use in extemporaneous topical formulations. Emulsions containing vitamin $\mathrm{E}$ and coconut oil (2:3) as lipid phase and different concentrations $(1.5-5.0 \% \mathrm{w} / \mathrm{w})$ of ACS (or Tween80®) in phosphate buffer as aqueous phase were formulated at $27 \pm 2{ }^{\circ} \mathrm{C}$. , Droplet sizes and shapes, $\mathrm{pH}$ and rheological properties were evaluated. Acidified CS was analysed using FTIR spectroscopy Emulsions stabilized with ACS and Tween $80^{\circledR}$ were cream and yellow coloured respectively, with the intensity of the colour increasing as the concentration increased. The emulsions were non-offensive and easily re-dispersed on shaking. Emulsions containing ACS had larger droplet sizes (18.34 $\pm 1.14-33.27 \pm 1.32 \mu \mathrm{m})$ and were more spherically shaped with higher $\mathrm{pH}$ values(6.80-6.95), showing dilatant and pseudoplastic flows at low and high shear rates respectively. The viscosity of emulsions stabilized at $2.5 \% \mathrm{w} / \mathrm{w}$ and $5.0 \% \mathrm{w} / \mathrm{w}$ remained unchanged after seven days. Acidified corn starch has stabilizing potentials comparable with Tween $80 ®$ when incorporated in vitamin E enriched coconut oil emulsions for extemporaneous topical formulations.
\end{abstract}

Keywords: Coconut oil emulsions; Vitamin E; Acidified corn starch; Tween80 ${ }^{\circledR}$; Viscosity Emulsion stability, Extemporaneous topical formulations

\section{INTRODUCTION}

The thermodynamic stability of a pharmaceutical emulsion is a template that formulators use in determining the quality, efficacy and consequently the safety of such dosage form [1]. Extemporaneous formulations (used for a relatively short period of not more than seven days) are expected to satisfy dosage requirements that are not commercially available [2]. In some situations, there may be need to incorporate medicaments in emulsions for topical use as extemporaneous formulations, thus necessitating the stability of such a system, even though it is for a relatively short period of time [3] To a large extent, the stability of emulsions depends on the constituents of the dispersed phase, which usually consists of the main ingredient, a stabilizer and an emulsifier [4] Anna et al [5] documented the better stability of monodisperse emulsions when compared with polydisperse emulsions under the same storage conditions. Several theories have been proposed to explain the intra component

*Correspondence. E-mail: adetunjioladapao@gmail.com Tel: +234-8055412280.

ISSN 0189-8442

2020. Published by Faculty of Pharmaceutical Sciences, University of Jos, Nigeria. Under Creative Commons Attribution-NonCommercial 4.0 International License. https://creativecommons.org/licenses/by-nc/4.0/ 
interaction of the emulsions [6]. Such theories include the surface tension theory, which describes the emulsification process as a consequence of reduction of the interfacial tension of the two immiscible components, leading to the conversion of large globules to smaller globules; the oriented wedge theory, which explains the stability of emulsions on the basis of polarity of the immiscible liquids [7] The interfacial film theory emphasizes the need to lower the interfacial energy and the strength of the interfacial film as a way of positively influencing the stability of emulsions [8]. Emulsifiers adsorb and concentrate at the interface between the oil and water, where they play a functional role in facilitating the emulsion process and prolonging the shelf life of the emulsions [9]. Coconut oil obtained from Cocos nucifera $L$. (Family: Arecaceace) has been used extensively in the synthesis of cosmetic detergents due majorly to its high content of saturated fatty acids such as lauric acid (monolaurin) and myristic acid [10], which has proven useful when applied topically to promote wound healing [11]. Coconut oil has also been used in ethno-medicine to treat injuries, minor-cuts and swellings [12]. The use of coconut oil as an ingredient in emulsions has been well documented in literature [11] [13]. However, the major setbacks of coconut oil emulsions are the low surface activity, poor emulsification characters and large droplet sizes [14]. Vitamin E, a lipid soluble vitamin, has been incorporated in pharmaceutical formulations [15], primarily due to its prooxidant properties, which makes it to function as a regulator of gene expression, consequently responsible for the ability of the vitamin to prevent the onset of chronic diseases [16]. The usual formulation problem associated with the use of vitamin $\mathrm{E}$ as an ingredient in emulsions is autoxidation [17], thus necessitating a stabilization system that will prevent lipid peroxidation during manufacture, storage and administration. Yang et al [18] successfully formulated vitamin $\mathrm{E}$ capsules at a temperature of $20-80^{\circ} \mathrm{C}$ over a $\mathrm{pH}$ range of $2-8$. It is expected that if the conditions are modified and a surfactant is incorporated, vitamin $\mathrm{E}$ enriched coconut oil emulsions may be sufficiently stabilized. Polysorbate 80 (Tween $80^{\circledR}$ ) has been extensively used as a standard surfactant/stabilizer in emulsion technology. Khan et al developed a pharmaceutical O/W emulsion containing plant-derived polyphenol extracts and evaluated its stability and antioxidant activity using polysorbate 80 (Tween 80®) as standard [19]. The stability of Vitamin E enriched nano emulsions stabilized by octenyl succinic anhydride modified starch was also reported by Hategekimana et al [20]. Corn starch is a widely used excipient in the pharmaceutical industry, where it functions as a thickener, stabilizer and gelling agent [21]; however, the preclusion of the application of native corn starch in the pharmaceutical industry is based on certain setbacks, such as poor solubility, poor flow properties and high hydrophilicity, that have necessitated the need to modify starches to achieve the objective of the formulation scientist in ensuring the production of standard dosage forms, thereby circumventing the limitations inherent in the use of native starch as pharmaceutical ingredients. Thus, several chemical modifications of starch, such as acidification, has been carried out to enhance its functionality [1]. In the present study, the stabilization potentials of acidified corn starch in coconut oil emulsions enriched with Vitamin $\mathrm{E}$ for extemporaneous topical formulations was compared with similar formulations containing polysorbates 80 (Tween $80^{\circledR}$ ).

\section{EXPERIMENTAL}

Extraction of coconut oil. Manual separation of the fresh endosperm of coconut (Cocos nucifera, Family: Arecaceace) from the shells was done and the endosperms were then washed with ultra-pure water (UPW). The 
washed endosperms were cut into small pieces, weighed and milled using a Kenwood blender. Slightly warmed UPW was mixed with the resulting mass for about 2 min before filtering using muslin cloth. The process was repeated severally to ensure thorough extraction of the milky oil which was boiled for a period of 15 min. The cooled oil was decanted and refiltered to obtain the coconut oil (CO) which was stored in an air-tight container.

Acidification of corn starch. Corn starch BP (200 g) was acidified by soaking with $400 \mathrm{~mL}$ of $6 \% \mathrm{w} / \mathrm{v}$ hydrochloric acid (HCL) for 192 hours and then decanted. The slurry was neutralized with $3 \%$ w/v Sodium hydroxide for $24 \mathrm{~h}$ and decanted. Sufficient quantity of UPW was used to rinse the slurry repeatedly to remove any excess hydroxide ions prior to drying in the oven at $40{ }^{0} \mathrm{C}$ for $24 \mathrm{~h}$. The resulting acidified corn starch (ACS) was stored in an air tight container.

Iodine test for confirmation of acidified starch integrity. The integrity of ACS was confirmed using the iodine test. A small quantity ( $1 \mathrm{~g}$ ) of the ACS was transferred to a porcelain dish and few drops of N/50 iodine solution was added. The colour change was observed.

\section{Confirmation of acidification using Fourier} Transform Infrared (FTIR) spectroscopy. Spectra were obtained for the powdered samples of corn starch BP and ACS using a magma-IR 560 FTIR spectrometer (Perkin Elmer, USA). About 5.0 $\pm 0.2 \mathrm{mg}$ of powdered samples was weighed and dispersed in $200 \mathrm{mg}$ finely pulverized potassium bromide pellets. A force of approximately 8 tons was applied under vacuum (with degassing to eliminate air and moisture from the potassium bromide powder) transparent pellets were obtained. The pellets were scanned at a range of $400-4000 \mathrm{~cm}^{-1}$.

Preparation of vitamin E enriched coconut oil emulsions. The aqueous phase was ACS or Tween $80^{\circledR}$ in phosphate buffer ( $\mathrm{pH} 7.0$ ), while the lipid phase was a mixture of vitamin E and CO. The oil-in-water emulsions were prepared using a homogenizer (Silverson Machine LTD Water side Cheshman Bucks, England). Eight formulations (labelled A- H) were formulated as shown in Table 1.

\section{Determination of physicochemical properties of emulsions}

Evaluation of physical appearance. The emulsions, formulated as vehicles for extemporaneous drug delivery, were physically observed over a seven-day period for any changes in appearance (colour and redispersibility). Why was 7 days chosen? Hope you have explanation at the discussion section

Determination of globule size, shape and emulsion index. A few drops of emulsion sample were placed on a glass slide and focused on the light microscope (Gallenkamp MNH550-R, Germany). The diameter of the emulsion globules was determined with the aid of the eye piece micrometer fixed to the microscope. The shapes of the globules were also observed and recorded. This procedure was repeated for each emulsion batch in triplicates on days 1, 3 and 7. The emulsion index (EI) of each batch was calculated after $24 \mathrm{~h}$ of emulsification as described by Rayner and Dejmek [15] using the equation below:

$\mathrm{EI}=\frac{\text { Volume of Foam formed (Vf) }}{\text { Total volume of emulsion (Tf) }}$

(Eq: 1)

Determination of $\mathrm{pH}$. The $\mathrm{pH}$ meter (Jenway Model 3520, Essex, United Kingdom) was calibrated and the electrode was cleaned with UPW. The electrode was immersed in the different emulsion samples, stirred for a few minutes and the readings were recorded in triplicates for each sample batch.

Evaluation of rheological properties of emulsions. The viscosity of the different batches of emulsions was evaluated using spindle 3 of a Brookfield viscometer (VT 181, Karlsruhe, Germany) set at different shear rates of $10,20,50,60$ and $100 \mathrm{rpm}$. The 
readings in centipoise were recorded in triplicates.

\section{RESULTS AND DISCUSSION}

Confirmation of starch. Amylose has unique physicochemical properties that determine the linearity of any starch material. The strong affinity of amylose for iodine can be used as a qualitative marker to determine the level of degradation that the starch has been exposed to [22] A deep blue coloration was obtained after $\mathrm{N} / 50$ iodine solution was added to the ACS. This is to ensure that the sample still retained its amylose content, thus confirming that the starch integrity was not compromised due to the acidification procedure.

Fourier Transform Infrared (FTIR) spectroscopy. The FTIR plots of the corn starch BP and the ACS are shown in Fig-3. Acidification of corn starch using HCL led to the presence of hydrogen atoms bonded to $\mathrm{Sp}^{2}$ hybridized carbon atoms at $2353.90 \mathrm{~cm}^{-1}$, thus leading to a broadening occurring at position $2370.70 \mathrm{~cm}^{-1}$. In the finger print region, significant changes were not observed indicating that the integrity of the starch was maintained.

Physical appearance of emulsions. The appearance, colour and re-dispersibility of emulsions can be used in characterizing the stability of emulsions. These properties depend on the characteristics of the aqueous and lipid phases [23]. Table 2 shows the appearance of the emulsions over a seven-day period. The emulsions that contained Tween $80 \AA$ became brighter in colour with increase in concentration; cloudiness and turbidity were also observed towards day seven, with creaming of emulsions noticed with concentrations $1.5 \% \mathrm{w} / \mathrm{w}$ and $2.5 \% \mathrm{w} / \mathrm{w}$. The emulsions containing ACS retained their colour throughout the seven-day period with no significant change in colour intensity. Emulsions that contained $3.5 \% \mathrm{w} / \mathrm{w}$ and 5.0 $\% \mathrm{w} / \mathrm{w}$ ACS were turbid and cloudy respectively on day seven, while creaming was observed on day 7 for the emulsion containing $1.5 \% \mathrm{w} / \mathrm{w}$ ACS. Generally, all the emulsions formulated were easily re-dispersed on shaking.

\section{Globule size and shape and emulsion index.} The droplet size and shape of the emulsions are shown in Table 3. Thermodynamic stability of emulsions could be influenced by globular sizes, and stability has been documented to increase when interfaces are lined with small particles of the emulsifying agent, thus emphasizing the functional role that globule size plays in this regard [24]. Emulsions containing Tween $80^{\circledR}$ had lower mean globule sizes than emulsions containing ACS. This observation of difference in globular sizes could be due to increased attractive interdroplet interaction and aggregation, leading to enhanced sizes of the globules. Changes in interfacial packing could also contribute to the structural changes noticed in the sizes due to migration of water from the aqueous phase [14]. However, at a concentration of $5 \% \mathrm{w} / \mathrm{w}$, the globule sizes became comparable with each other. Particle shape also contributes to the stability of emulsions. Generally, starches show strong attachment between oil/water interfaces that could be difficult to reverse due to the high energy of detachment needed to achieve the reversal [25]. Moreover, particles that are shaped towards sphericity have been documented to also contribute to emulsion stability [26]. The significance of globule shape was also emphasized by Madivala et al [27] when they highlighted critical properties of pickering emulsions stabilized by particles that gave different globule shapes, with spherically shaped particles dispersing well and subsequently forming stable droplets. However, the emulsions containing ACS had spherically shaped particles, while there were more oval shaped particles in the emulsions stabilized containing Tween $80^{\circledR}$ throughout the seven-day period. 
Macro et al [28] documented that the EI of an emulsifying agent can be used to predict its stability potential in the emulsion. Hence, the closer the EI value is to 1, the higher the stabilization potential of the emulsifying agent [29]. The EI were observed to increase with increase in the concentration of the emulsifying agents (Tween $80^{\circledR}$ and ACS), however, emulsions containing ACS had higher EI values when compared with emulsions containing Tween $80^{\circledR}$. Also, the increase in the concentration of the ACS had significant increase in the EI values, thus suggesting that ACS had better stabilization potential than Tween $80^{\circledR}$. This could also be inferred from the physical appearance of the emulsions as ACS was able to slow down the rate of creaming when compared with Tween $80^{\circledR}$.

Table 1: Formula of vitamin E enriched coconut oil emulsions

\begin{tabular}{clc}
\hline Batch number & Lipid phase $(12.5 \% \mathrm{w} / \mathrm{w})$ & $\begin{array}{c}\text { Aqueous phase }(87.5 \% \mathrm{w} / \mathrm{w}) \\
\text { (in phosphate buffer, pH 7.0) }\end{array}$ \\
\hline $\mathrm{A}$ & Vitamin E : CO $(2: 3)$ & $1.5 \% \mathrm{w} / \mathrm{w}$ Tween $80^{\circledR}$ \\
$\mathrm{B}$ & Vitamin E : CO $(2: 3)$ & $2.5 \% \mathrm{w} / \mathrm{w}$ Tween $80^{\circledR}$ \\
$\mathrm{C}$ & Vitamin E : CO $(2: 3)$ & $3.5 \% \mathrm{w} / \mathrm{w}$ Tween $80^{\circledR}$ \\
$\mathrm{D}$ & Vitamin E : CO $(2: 3)$ & $5.0 \% \mathrm{w} / \mathrm{w}$ Tween $80^{\circledR}$ \\
$\mathrm{E}$ & Vitamin E : CO $(2: 3)$ & $1.5 \% \mathrm{w} / \mathrm{w}$ ACS \\
$\mathrm{F}$ & Vitamin E : CO $(2: 3)$ & $2.5 \% \mathrm{w} / \mathrm{w}$ ACS \\
$\mathrm{G}$ & Vitamin E : CO $(2: 3)$ & $3.5 \% \mathrm{w} / \mathrm{w}$ ACS \\
$\mathrm{H}$ & Vitamin E : CO $(2: 3)$ & $5.0 \% \mathrm{w} / \mathrm{w}$ ACS \\
\hline & $\mathrm{CO}=$ Coconut Oil, ACS $=$ Acidified Corn Starch
\end{tabular}

Table 2: Physical appearance of emulsions

\begin{tabular}{|c|c|c|c|c|c|}
\hline \multirow[t]{2}{*}{ Batch } & \multicolumn{5}{|c|}{ Physical appearance at $27 \pm 2^{\circ} \mathrm{C}$} \\
\hline & Day $1(6 \mathrm{~h})$ & Day 2 & Day 3 & Day 4 & Day 7 \\
\hline $\mathrm{A}$ & $\begin{array}{l}\text { Bright yellow } \\
\text { coloration }\end{array}$ & $\begin{array}{l}\text { Dull yellow } \\
\text { coloration }\end{array}$ & $\begin{array}{l}\text { Dull yellow } \\
\text { coloration }\end{array}$ & $\begin{array}{l}\text { Dull and cloudy } \\
\text { yellow coloration with } \\
\text { creaming }\end{array}$ & $\begin{array}{l}\text { Dull and cloudy } \\
\text { yellow coloration } \\
\text { with creaming }\end{array}$ \\
\hline B & $\begin{array}{l}\text { Bright yellow } \\
\text { coloration }\end{array}$ & $\begin{array}{l}\text { Bright yellow } \\
\text { coloration }\end{array}$ & $\begin{array}{l}\text { Bright yellow } \\
\text { coloration }\end{array}$ & $\begin{array}{l}\text { Dull and cloudy } \\
\text { yellow coloration } \\
\text { with creaming }\end{array}$ & $\begin{array}{l}\text { Dull and cloudy } \\
\text { yellow coloration } \\
\text { with creaming }\end{array}$ \\
\hline $\mathrm{C}$ & $\begin{array}{l}\text { Slightly intense } \\
\text { yellow coloration }\end{array}$ & $\begin{array}{l}\text { Slightly intense } \\
\text { yellow coloration }\end{array}$ & $\begin{array}{l}\text { Slightly intense } \\
\text { yellow coloration }\end{array}$ & $\begin{array}{l}\text { Dull and cloudy } \\
\text { yellow coloration }\end{array}$ & $\begin{array}{l}\text { Dull and cloudy } \\
\text { yellow coloration }\end{array}$ \\
\hline $\mathrm{D}$ & $\begin{array}{l}\text { Golden yellow } \\
\text { coloration }\end{array}$ & $\begin{array}{l}\text { Golden yellow } \\
\text { coloration }\end{array}$ & $\begin{array}{l}\text { Golden yellow } \\
\text { coloration }\end{array}$ & $\begin{array}{l}\text { Dull and cloudy } \\
\text { yellow coloration with } \\
\text { creaming }\end{array}$ & $\begin{array}{l}\text { Dull and cloudy } \\
\text { yellow coloration } \\
\text { with creaming }\end{array}$ \\
\hline $\mathrm{E}$ & $\begin{array}{l}\text { Cream coloured } \\
\text { emulsion }\end{array}$ & $\begin{array}{l}\text { Cream coloured } \\
\text { emulsion }\end{array}$ & $\begin{array}{l}\text { Cream coloured } \\
\text { emulsion }\end{array}$ & $\begin{array}{l}\text { Cream coloured } \\
\text { emulsion }\end{array}$ & $\begin{array}{l}\text { Cream coloured } \\
\text { emulsion with } \\
\text { creaming }\end{array}$ \\
\hline $\mathrm{F}$ & $\begin{array}{l}\text { Cream coloured } \\
\text { emulsion }\end{array}$ & $\begin{array}{l}\text { Cream coloured } \\
\text { emulsion }\end{array}$ & $\begin{array}{l}\text { Cream coloured } \\
\text { emulsion }\end{array}$ & $\begin{array}{l}\text { Cream coloured } \\
\text { emulsion }\end{array}$ & $\begin{array}{l}\text { Cream coloured } \\
\text { emulsion }\end{array}$ \\
\hline G & $\begin{array}{l}\text { Cream coloured } \\
\text { emulsion }\end{array}$ & $\begin{array}{l}\text { Cream coloured } \\
\text { emulsion }\end{array}$ & $\begin{array}{l}\text { Cream coloured } \\
\text { emulsion }\end{array}$ & $\begin{array}{l}\text { Cream coloured } \\
\text { emulsion }\end{array}$ & $\begin{array}{l}\text { Cream coloured } \\
\text { turbid emulsion }\end{array}$ \\
\hline $\mathrm{H}$ & $\begin{array}{l}\text { Cream coloured } \\
\text { emulsion }\end{array}$ & $\begin{array}{l}\text { Cream coloured } \\
\text { emulsion }\end{array}$ & $\begin{array}{l}\text { Cream coloured } \\
\text { emulsion }\end{array}$ & $\begin{array}{l}\text { Cream coloured } \\
\text { cloudy emulsion }\end{array}$ & $\begin{array}{l}\text { Cream coloured } \\
\text { cloudy emulsion }\end{array}$ \\
\hline
\end{tabular}

$\mathrm{N}: \mathrm{B}:$ All the emulsions were easily re-dispersed on shaking.

Table 3: Table showing the mean globule sizes and shapes of the different emulsion batches

\begin{tabular}{lll}
\hline Batch & Globule shape and size $(\mu \mathrm{m}), \mathrm{n}=10 \pm \mathrm{SD}$ & Emulsion Index \\
\hline
\end{tabular}




\begin{tabular}{|c|c|c|c|c|}
\hline & Day 1 (after $6 \mathrm{~h})$ & Day 3 & Day 7 & $(24 \mathrm{~h})$ \\
\hline A & $\begin{array}{c}\text { Spherical } \\
(2.94 \pm 0.10)\end{array}$ & $\begin{array}{c}\text { Oval } \\
(2.97 \pm 0.22)\end{array}$ & $\begin{array}{c}\text { Oval } \\
(3.02 \pm 0.11)\end{array}$ & $0.43 \pm 1.11$ \\
\hline B & $\begin{array}{c}\text { Spherical } \\
(4.76 \pm 0.14)\end{array}$ & $\begin{array}{c}\text { Oval } \\
(5.88 \pm 0.12)\end{array}$ & $\begin{array}{c}\text { Oval } \\
(5.96 \pm 0.21)\end{array}$ & $0.45 \pm 0.13$ \\
\hline $\mathrm{C}$ & $\begin{array}{c}\text { Spherical } \\
(6.02 \pm 0.26)\end{array}$ & $\begin{array}{c}\text { Oval } \\
(6.17 \pm 0.15)\end{array}$ & $\begin{array}{c}\text { Oval } \\
(6.28 \pm 0.23)\end{array}$ & $0.46 \pm 1.03$ \\
\hline $\mathrm{D}$ & $\begin{array}{c}\text { Spherical } \\
(17.50 \pm 0.84)\end{array}$ & $\begin{array}{c}\text { Spherical } \\
(18.62 \pm 0.22)\end{array}$ & Mostly oval with few spherical(19.50 0.18$)$ & $0.49 \pm 0.11$ \\
\hline $\mathrm{E}$ & $\begin{array}{c}\text { Spherical } \\
(18.34 \pm 1.14)\end{array}$ & $\begin{array}{c}\text { Spherical } \\
(20.37 \pm 0.44)\end{array}$ & $\begin{array}{c}\text { Spherical } \\
(21.07 \pm 1.08)\end{array}$ & $0.62 \pm 1.08$ \\
\hline$F$ & $\begin{array}{c}\text { Spherical } \\
(32.20 \pm 1.52)\end{array}$ & $\begin{array}{c}\text { Spherical } \\
(33.17 \pm 1.11)\end{array}$ & $\begin{array}{c}\text { Spherical } \\
(33.27 \pm 1.32)\end{array}$ & $0.69 \pm 0.03$ \\
\hline $\mathrm{G}$ & $\begin{array}{c}\text { Spherical } \\
(28.84 \pm 1.61)\end{array}$ & $\begin{array}{c}\text { Spherical } \\
(29.27 \pm 1.58)\end{array}$ & Mostly spherical (30.02 \pm 1.17$)$ & $0.74 \pm 0.12$ \\
\hline $\mathrm{H}$ & $\begin{array}{c}\text { Spherical } \\
(19.74 \pm 0.51)\end{array}$ & $\begin{array}{c}\text { Spherical } \\
(20.03 \pm 1.21)\end{array}$ & $\begin{array}{c}\text { Spherical } \\
(20.33 \pm 1.18)\end{array}$ & $0.76 \pm 0.11$ \\
\hline
\end{tabular}

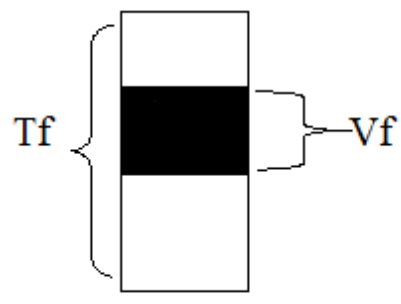

Fig-2: Schematic diagram used in calculating emulsion index

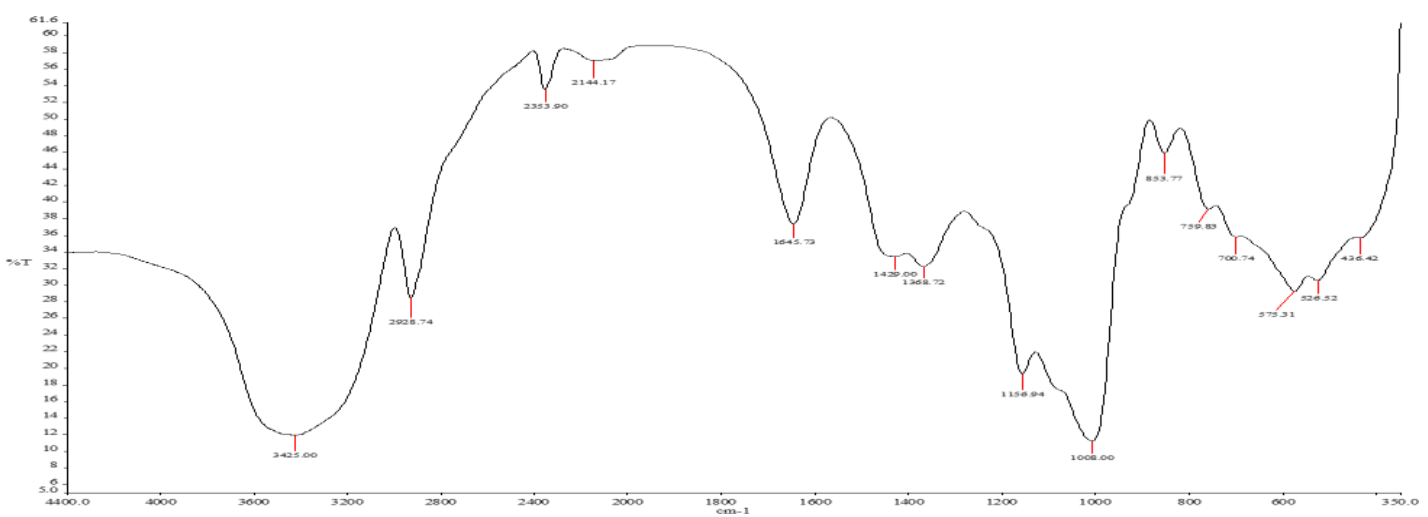

Figure 3a: FTIR plot of native corn starch 
O.A. Adetunji \& T.O. Akingbade /J. Pharmacy \& Bioresources 17(2), 153-163 (2020)

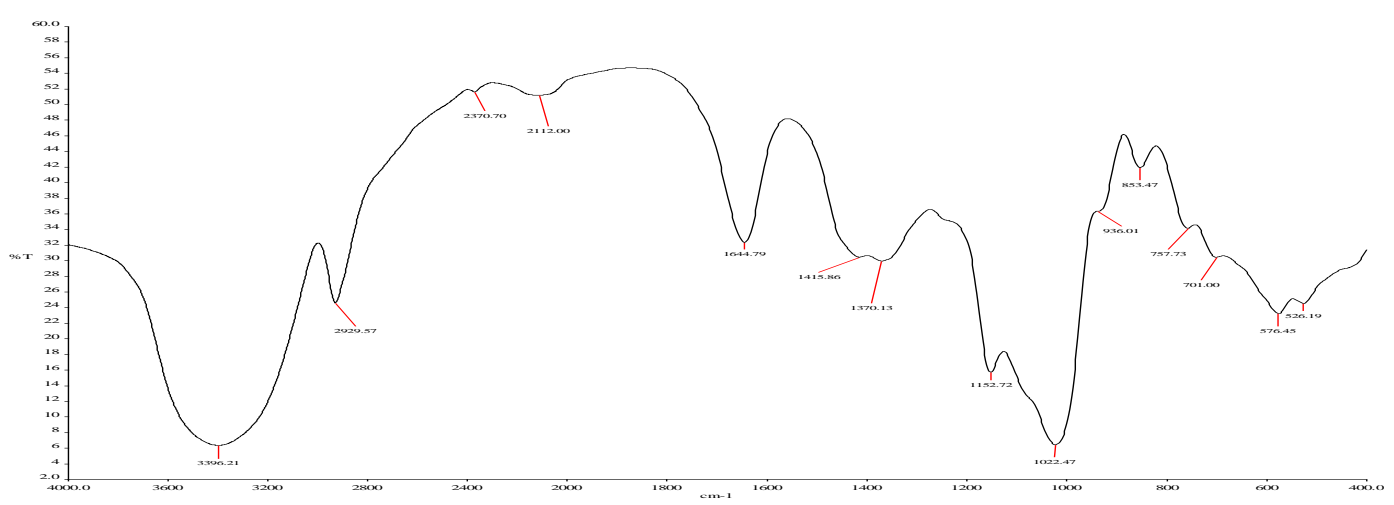

Figure. 3b: FTIR plot of ACS

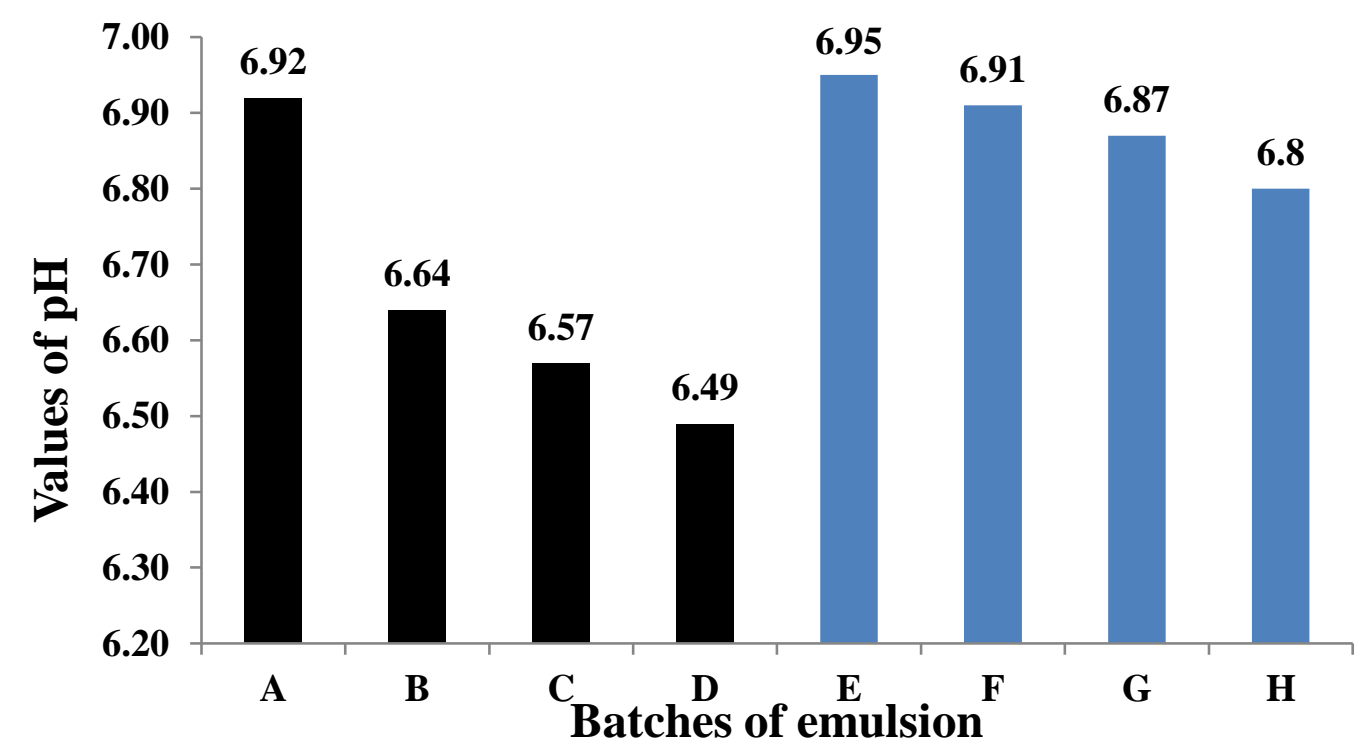

Figure 4: Representative plot of $\mathrm{pH}$ of emulsions 


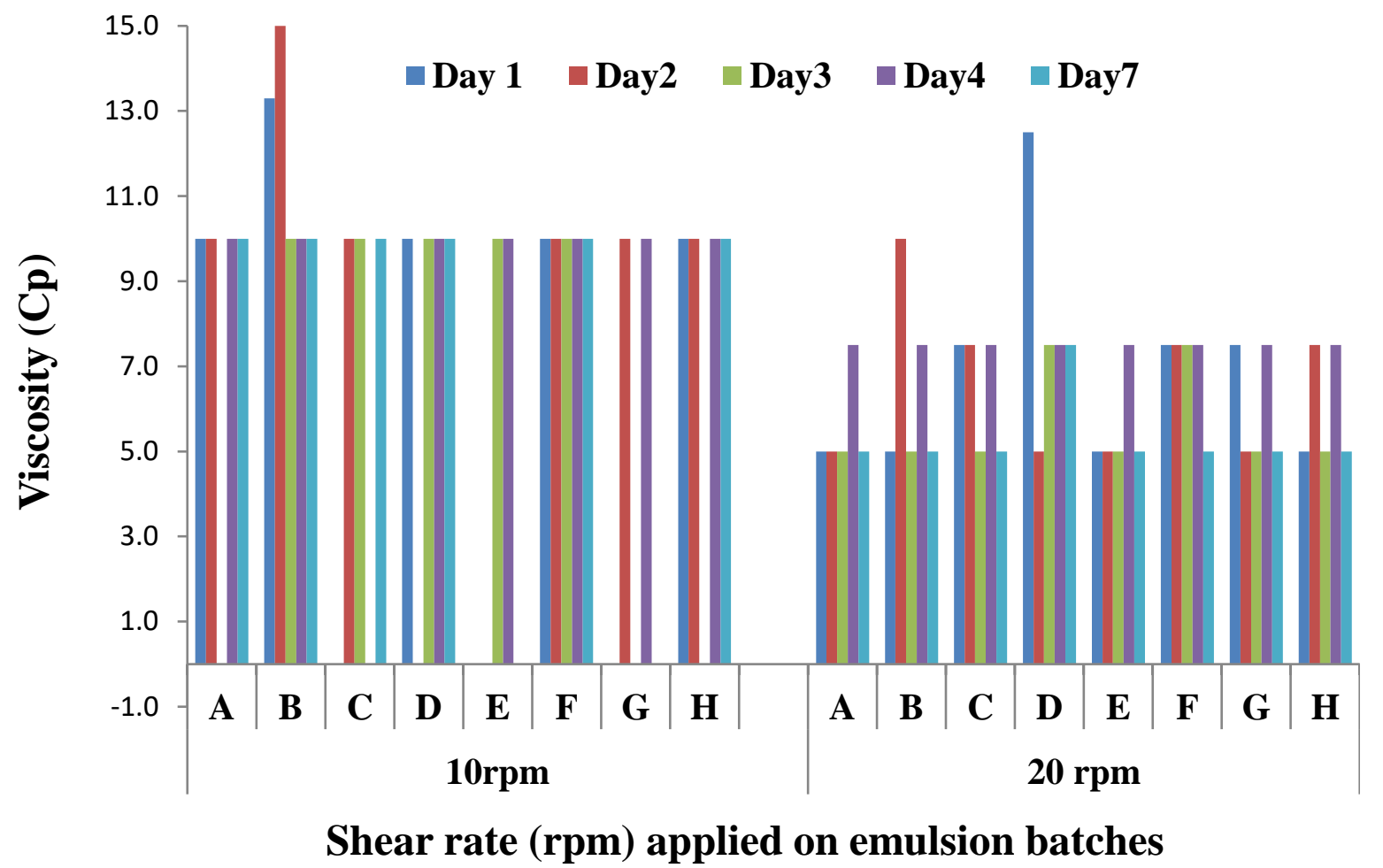

Figure 5a: Viscosity (Cp) of emulsions against Shear rate (10 rpm and $20 \mathrm{rpm}$ )

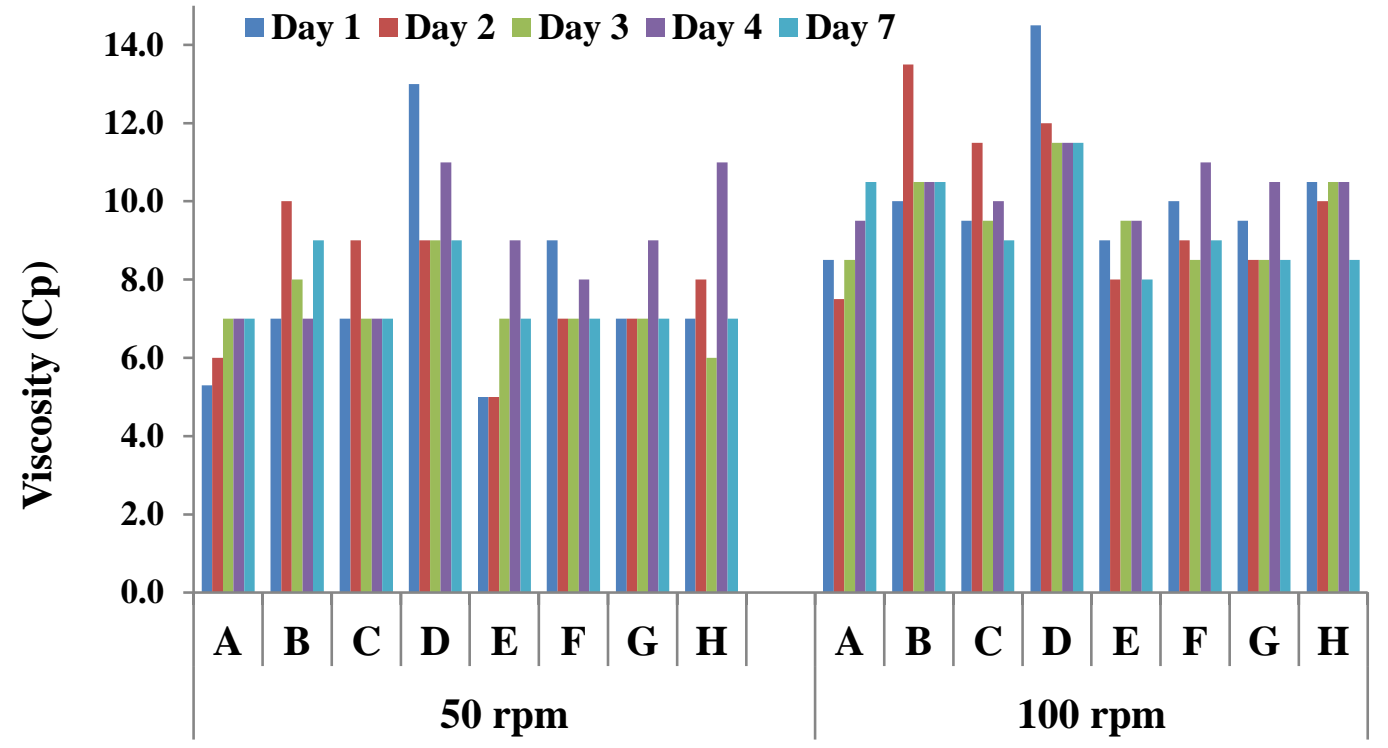

Shear rate (rpm) applied on emulsion batches

Figure 5b: Viscosity (Cp) of emulsions against Shear rate (50 rpm and $100 \mathrm{rpm})$

Hydrogen potency ( $\mathrm{pH})$ of emulsions

The $\mathrm{pH}$ of an emulsion is attributed to the ionisation of surface-active polar groups which induce sufficient electrostatic repulsive interactions to breakdown the interfacial film cohesion, thereby influencing the stability of 
the emulsions [30]. It can also be used to determine the site of application of the emulsion. There was no significant change in the $\mathrm{pH}$ of the emulsions over the seven-day period, and a representative plot of the $\mathrm{pH}$ of the emulsions, which followed a similar pattern is given in Fig-4. Emulsions containing ACS were more weakly acidic (6.49-6.92) than those stabilized with Tween $80^{\circledR}(6.8-6.95)$. Also, it was observed that the concentration of the stabilizer and the $\mathrm{pH}$ of the emulsion had an inverse relationship. For topical administration, it is important that the $\mathrm{pH}$ of the medicament is kept weakly acidic as alkaline $\mathrm{pH}$ are particularly detrimental the skin [31]. This suggests that the emulsions containing $5.0 \% \mathrm{w} / \mathrm{w}$ emulsifiers have good potentials for use in topical dosage forms.

\section{Rheological properties of emulsions.} Viscosity is defined as a measure of resistance to deformation by shear stress or tensile stress [32]. Viscosity depends on the droplet size, shear rate, droplet size distribution and density of the oil; which are influenced by the type of emulsifying agent incorporated in the formulation [33]. Emulsions generally exhibit non-Newtonian flow behaviour at low shear rate and Newtonian flow behaviour at high shear rate [34]. The behaviour of nonNewtonian fluids can be pseudoplastic, dilatant, rheopectic and thixotropic [35]. The representative plots of the viscosity profiles of the emulsions are shown in Fig 5 ( $a$ and $b$ ). An inverse relationship was observed between the shear rate and viscosity when the shear rate was increased from $10 \mathrm{rpm}$ to $20 \mathrm{rpm}$, thus indicating dilatant (shear thickening) behaviour, while an increase in viscosity was observed at a high shear rate $(50 \mathrm{rpm}$ to 100 $\mathrm{rpm}$ ), which is an indication of pseudoplastic (shear thinning) behaviour. These observations were also reported by Chhabra et al [34]. These characteristics, which are peculiar to non-Newtonian fluids, is a result of the re-ordering pattern of constituent particles after the application of shear, which is low (increased viscosity) when a small shear rate is applied and vice versa [36]. It can be deduced from the plots that comparable viscosity profiles were observed for emulsions containing $3.5 \% \mathrm{w} / \mathrm{w}$.

In conclusion, emulsions containing ACS maintained the colour intensity with lower rate of creaming, had higher droplet sizes, and were more spherical with higher emulsion indices when compared with emulsions containing Tween $80^{\circledR}$. Due to the weakly acidic $\mathrm{pH}$ at concentrations of $5 \% \mathrm{w} / \mathrm{w}$, the emulsions demonstrated potentials for use in topical drug delivery. The viscosity values of the emulsions were affected by the shear rates, which caused shear thickening and thinning at low and high shear rates respectively. Thus, acidified corn starch has good stabilization potentials in the emulsions formulated that are comparable with Tween $80^{\circledR}$.

\section{REFERENCES}

1. Adetunji, O.A. (2019); Chemically modified starches as excipients in pharmaceutical dosage forms. In: Chemical Properties of Starch, Ed: Emeje M. (ISBN 978-1-83880-116-

8) https://www.intechopen.com/books/chemicalproperties-of-starch/chemically modified-starches-asexcipients-in-pharmaceutical-dosage-forms

2. Handbook of Extemporaneous Preparations. $\mathrm{h}$ ttps://www.pharmpress.com/files/docs/HandbookExt emporaneousPreparation_Sample.pdf; 2016, Assessed on 02 February, 2020.

3. Krochmal, L. and Patel, B. (1992); Topical product design and extemporaneous compounding in dermatology; J. Adv. Dermatol., 7, 231-52

4. Akbari, S. and Nour, A. H. (2018); Emulsion types, stability mechanisms and rheology: a review; Int. J. Inn. Res. Sci. S., 1(1), 14-21.

5. Anna, M., Laura, S. and Olga, M. (2018); Beverage emulsions: keys aspects of their formulation and physicochemical stability; J. Bev. 4(3), 70-72.

6. Khan, B.A., Akhtar, N., Khan, H.M., Waseem, K., Mahmood, T., Rasul, A., Iqbal, M. and Khan, H (2011); Basics of pharmaceutical emulsions: a review; Afr. J. Pharm. Pharmacol. 5(25), 2715-2725 
7. Kabalnov, A. and Wennerström, H. (2012); Macroemulsion stability: the oriented wedge theory revisited; Langm., 22, 276-292.

8. Qing, C.( 2016); Emulsion, foam and gel. In: Colloids and interface chemistry for water quality control ( $1^{\text {st }}$ edition$)$, Ed: Qing C. Academic press. pp. 227-245.

9. Leal-Calderon, F. (2012); Emulsified lipids: Formulation and control of end-use properties; J. Oleag. Lip. 19(2),111-119.

10. Maestri, M.; Labuckas, D.O.; Guzmán, C.A. and Giorda, L.M. (1998); Correlation between seed size, protein and oil contents, and fatty acid composition in soybean genotypes; J. Gra. Ace. 49, 450-453.

11. Nevin, K.G. and Rajamohan, T. (2010); Effect of topical application of virgin coconut oil on skin components and antioxidant status during dermal wound healing in young rats; Skin Pharmac. Physio. 23, 290-297.

12. Lans, C. (2007); Comparison of plants used for skin and stomach problems in Trinidad and Tobago with Asian ethnomedicine. J. Ethnobio. Ethnomed. 3, 3-14.

13. Biruss, B.; Kahlig, H. and Valenta, C. (2007); Evaluation of a eucalyptus oil containing topical drug delivery system for selected steroid hormones. Int. J. Pharm. 328(2), 142-151.

14. Ja'Afar, S. M., Khalid, R. M., Othaman, R., Mokhtar, W.N.A.W. and Ramli, S. (2019); Coconut oil based microemulsion formulations for hair care product application. J. Rheo. Sci. 48(3), 599-605.

15. Ke, W.T., Lin, S.Y., Ho, H.O. and Sheu, M.T. (2005); Physical characterizations of microemulsion systems using tocopheryl polyethylene glycol 1000 succinate (TPGS) as a surfactant for the oral delivery of protein drugs. J. Cont. Rel.102, 489-507.

16. Yang, Y. and McClements, D.J. (2013); Encapsulation of vitamin $\mathrm{E}$ in edible emulsions fabricated using a natural surfactant. J. Food Hydroco. 30, 712-720.

17. Mayer, S., Weiss, J. and McClements, D.J. (2013); Behavior of vitamin E acetate delivery systems under simulated gastrointestinal conditions: lipid digestion and bioaccessibility of low-energy nanoemulsions. J. Coll. Int. Sci. 15, 215-22.

18. Yang, Y., Leser, M.E., Sher, A.A. and McClements, D.J.(2013); Formation and stability of emulsions using a natural small molecule surfactant:
Quillaja saponin (Q-Naturale®). J. Food Hydroco. 30, 589-596.

19. Khan, B.A., Akhtar N., Khan H. and Braga B. (2013); Development, characterization and antioxidant activity of polysorbate based $\mathrm{O} / \mathrm{W}$ emulsion containing polyphenols derived from Hippophae rhamnoides and Cassia fistula. Braz. J. Pharm. Sci. 49 (3), 763-773

20. Hategekimana, J., Bwengye, M.K., Masamba, K.G., Yokoyama, W. and Zhong, F. (2014); Formation and stability of vitamin e enriched nanoemulsions stabilized by octenyl succinic anhydride modified starch. Int. J. Food Engr. doi 10.1515/ijfe-2014-0159

21. Rayner, M. and Dejmek, P. (2015); Engineering aspects of food emulsification and homogenization, Ed(s): Rayner, M. and Dejmek, P., CRC Press.

22. Sunil, L.K. and Aramco, S. (2007); Crude and vegetable oil emulsions; In: Petroleum engineering handbook; ( $1^{\text {st }}$ edition $)$. Ed Larry, W.L. Soc. Pet. Engr. pp.533-570.

23. 16B. Kim, J.Y. and Huber, K. (2016); Preparation and characterization of corn starch$\beta$ carotene composites. Carbohydr. Polym., 136, 394401.

24. Aveyard, R. Binks, B.P. and Clint, J.H. (2003); Emulsions stabilised solely by colloidal particles; Adv. Coll. Int. Sci. 100 (2), 503 -546.

25. Taylor, S.D., Czarnecki, J. and Masliyah, J (2002); Disjoining pressure isotherms of water-inbitumen emulsion films; J. Coll. Int. Sci.252, 149160.

26. Rayner, M. (2012); Quinoa starch granules: a candidate for stabilizing food-grade pickering emulsions; Journal of the Science of Food and Agriculture 92(9), 1841-1847

27. Madivala, B., Vandebril, S., Fransaer, J., \& Vermant, J. (2009); Exploiting particle shape in solid stabilized emulsions. J. Soft Mat., 5(8), 1717. doi: $10.1039 / \mathrm{b} 816680 \mathrm{c}$

28. Macro, A.F., Roberto, C.O, Jorge, N.C. and Krishnaswamy, R. (2005); Viscosity of water-in-oil emulsions: variation with temperature and water volume fraction. J. Pet. Sc. Engr. 48(3), 169-184.

29. Mohsin, S., Akhtar, N., Mahmood, T. and Khan, H. (2016); Formulation and stability of topical water in oil emulsion containing corn silk extract; Trop. J. Pharm. Res. 15(6), 1115-1121.

30. Madaan, V., Chanana. A., Kataria, M.K. and Bilandi, A. (2014); Emulsion technology and recent 
trends in emulsion applications; Int. Res. J. Pharm. 5(7), 533-542.

31. Wataru, A. and Yoshinori, M. (2014); Importance of $\mathrm{pH}$ homeostasis in metabolic health and diseases: crucial role of membrane proton transport. Biomed. Res. Int. 10, 598-586 Article ID 598986. http://dx.doi.org/10.1155/2014/598986. Assessed on 02 February 2020.

32. Muhammed, A.R. and Samar, A.A. (2009); Effect of additives on rheological properties of invert emulsions. Iraq J. Chem. Pet. Engr. 10(3), 31-39.

33. Nevin, K.G. and Rajamohan, T. (2010); Effect of topical application of virgin coconut oil on skin components and antioxidant status during dermal wound healing in young rats. Skin Pharmac. Physio. 23 (1), 290-297.
34. Chhabra, R.P, and Richardson, J.F. (2008); Non- Newtonian fluid behaviour. In: Non-newtonian Flow and Applied Rheology. ( $2^{\text {nd }}$ edition). Butterworth-Heinemann. pp.1-55.

35. Palacios-Fonseca, A. J., Castro-Rosas, J., Gómez-Aldapa, C. A., Tovar-Benítez, T., MillánMalo, B. M., Del Real, A. and Rodríguez-García, M. E. (2013); Effect of the alkaline and acid treatments on the physicochemical properties of corn starch. J. Food Sci.11(1), 67-74.

36. Goodarzi F. and Zendehboudi S. (2018). A comprehensive review on emulsions and emulsion stability in chemical and energy industries. https://doi.org/10.1002/cjce.23336: Assessed on 03 August, 2020. 